症例

頝部食道外傷後経鼻胃管留置による胸部食道完全閉塞の 1 症例

虎の門病院消化器外科

宇田川 晴 司 鶴丸昌彦 鈴木正敏

同病理学科

小野由雅渡辺五朗秋山洋

武蔵野赤十字病院外科

海上雅 光原満

片岡卓三川島喜代志高橋勝三

食道の後天性良性狭窄の一因として経悬胃管留置の影響が古くから指摘されている か，末たこれによる食道完全閉塞の報告は例を見ない，最近我々は䅡部食道外第後，6 日間の経男管留置により胸部食道の完全閉塞を来たしたと思われる症例を経験した。

患者は19歳の女性で, 誤って割り箬を食道入口部後壁に突き刺して 2 時間後, 皮下気 畽に上る呼吸困難症状を訴之武蔵野赤十字病院に㗨急入院，3日後頝部食道瘦より右膿 胸を併発し開胸ドレナージ術を施行した。6日間の程鼻胃管留置の後これを抜去し1力 月前後の間に胸部食道が完全閉塞に陥った。虎の門病院転院後, 二期的に食道切除再建 術を施行したが切除標本において病変はほほ粘膜及び粘膜下層に限局しており，短期間 に発生した食道の全周性の上皮剝脱とそれに続く創傷治瘾過程として完成した食道閉塞 と推察された。術創の痖痕形成過鄱, 術後早期の癦着性イレウス等患者側の特殊因子も 推定された。

極めて稀な条件下に起った事態とは思われるが個々の誘因に関してはごく一般的に見 られるものであり，経鼻胃管留置に際しての留意点を明らかにすへく考察を加えた。

故引用語：後天性良性食道閉塞，食道外傷，経鼻胃管

\section{I. 緒 贯}

食道の後天性良性狭窄の一因として経奥胃管留置の 影響が古くから指摘されている゙ー8). 最近我々は䫓部 食道外傷後の経算留置によると思われる胸部食道 の完全閉塞の症例を経験した。 かかる症例は本例が最 初の報告と思われるが，経算置嵧と言らありふれ た処置が誘因と考えられる点臨床的に重要と考光，こ こに報告する。

\section{II. 症例}

患者：C.N. 19歳, 女性, 大学生.

主訴：経口摂取不能.

家族歴：特記すべきすのなし．

既往歴：特記すべきるのなし。

現病歴：昭和57年11月27日深夜, 夜食摄取中誤って 割り箸をのど突き刺したが，疼痛，出血むなく自力 で抜去した，2時間後呼吸困難出現。近医（耳囪科）
で酸素吸入,心マッサージ等施行の上, 武蔵野赤十字 病院に搬送された。

昭和57年11月28日頚部皮下気腫による気道狭窄と診 断された（图1).

11月29日ドレナーシの為䅡部皮席切開, 更に気管切 開を加えるす呼吸困難改善せず.

11 月 30 日䅡部創よりコーヒー残洫様液 $2,500 \mathrm{ml}$ 排 液.同日の胸部レ線写真より右膿胸と診断され緊急手 術施行. 右第 7 及び第 3 助間開胸で胸嘧内を観察する に右上縱隔の壁側胸膜に $3 \times 5 \mathrm{~cm}$ の裂創あり。ここに pleural patch を䋖着し胸腔洗浄, 胸腔ドレーンを留置 し閉胸した.

同日より12月 4 日までの 6 日間, 赤ゴム(天然ゴム) 製の経車胃管が挿入留置された。これはX-p 上も正し く胃内まで入っており，同チューブより最高 $2,000 \mathrm{ml} /$ d のコーヒー残渣様胃液が吸引された（cimetidine 投 


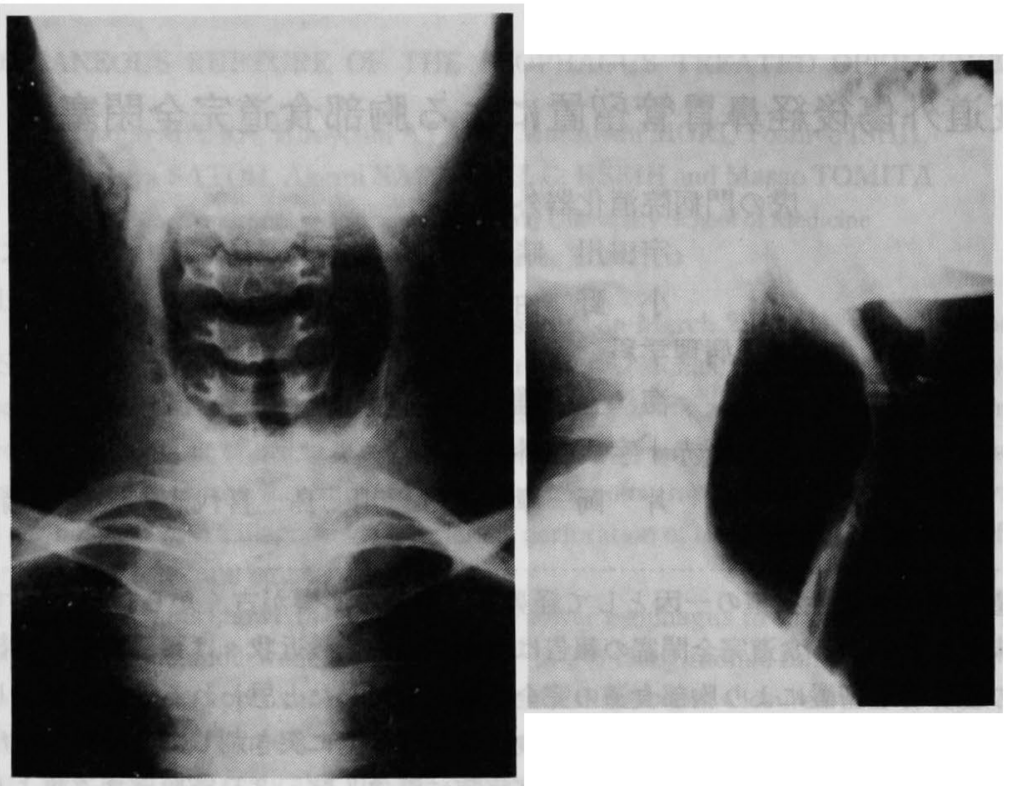

图 1 䫓部 Xp 一昭和57年11月28日一

与). 留道中, 胸焼け, 呕吐, 吐血なし. 抗凝固剂の使 用なし. 12 月 4 日胃管拔去時特に異常所見なし.

11月30日より12月27日をで顏部の瘦孔と右胸腔との 連続を断つ目的で患者は安静臥床の状態とされた。

12月23日経口的食道造影で頚部食道後壁の瘦孔を確 認(図 2 )。瘦孔に注目した造影の為不明瞭だがこの時

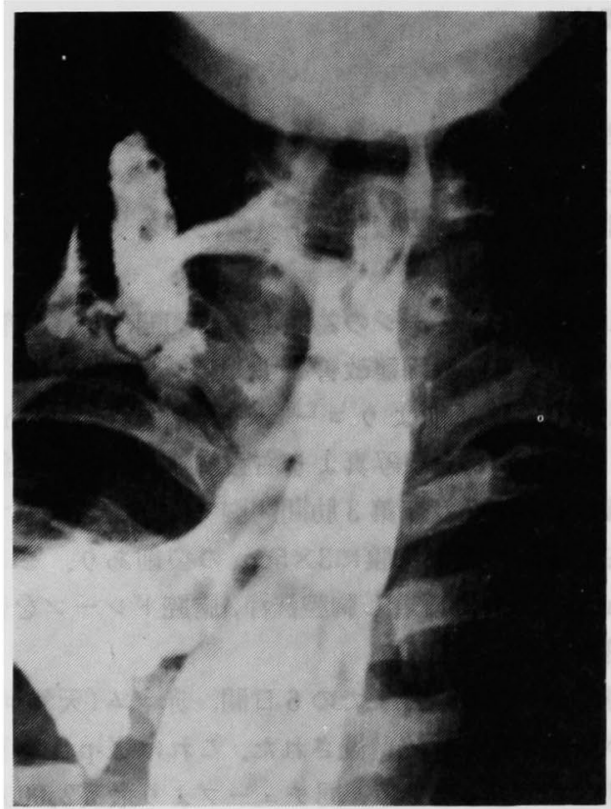

图 2 経口食道造影一昭和 57 年 12 月 23 日一
点で既に中部食道以下は造影されていない，臨床的に 発熱もなくそのまま経過観察とした。

以後昭和 58 年 1 月末日より輸血後肝炎と思われる肝 機能障害が見られたがその他は特に問題なく総てのド レーンは順次抜去され気管切開創も閉鎖され各創から の浸出るなくなった.

この間患者は唾液㗂下も含め一切の経口搷取を禁じ られ，IVH 管理下に置かれていた。昭和58年 1 月27日 再度食道造影を行らと頚部食道には瘦孔が残存し，胸 部中部食道は憩室様の所見を示しながら盲端となり， それより肛門側は造影されなかった（図了）。この所見 は 3 月末になってす变わらず内視鏡的にも同様であっ た，患者は唾液の無下も不能であった。 昭和58年 3 月 28 日虎の門病院消化器外科転入.

入院時所見：頝部，右胸部に手術瘦痕あり。総て hypertrophic scar の状態. 他, 理学検查上特に異常所 見なし．各種検査データ上も， ESR $19 \mathrm{~mm} / \mathrm{h}$, GOT 61 ku, GPT $52 \mathrm{ku}, \%$ VC 70\%の他特に問題となるすのな l.

入院後経過：咽頭㗋頭部の観察では中下咽頭後壁に 浮腫を認めるのみで声帯の動きる良好，梨状窩に pooling ななった.

経口的食道造影では頚部食道後壁に瘦孔を認め,こ こから上下の postcricoidal soft tissue 内に fistula cavity が広がり，下方は右上綎隔〜胸壁まで達してい 


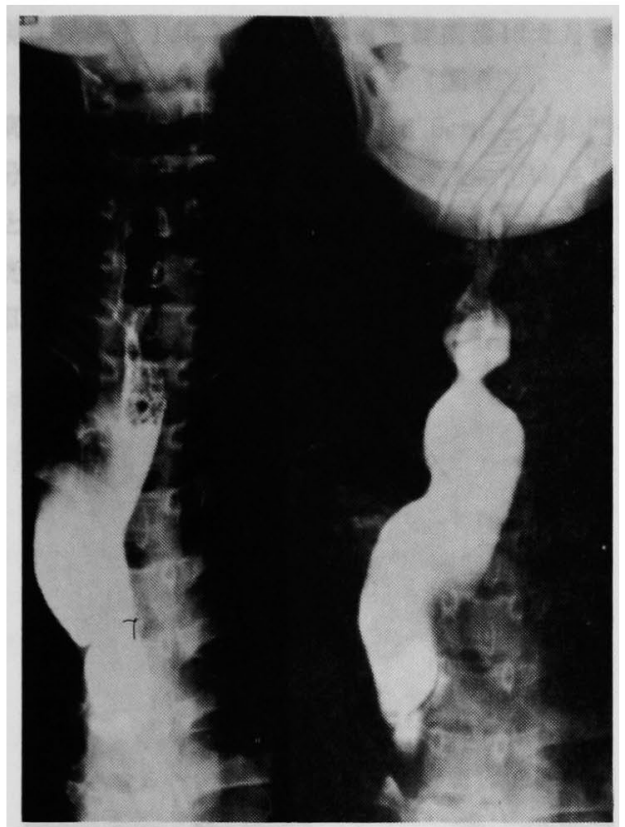

図 3 経口食道造影一昭和58年 1 月27日一。左：胸部 食道中部までしか造影されない，右：頝部食道㹟窄。

た、癭孔入口の上下で食道に軽度の狭窄が認められた （图 4 左）.胸部食道は中部で 2 つの垔状に払張し完全 閉塞しており，かなり加圧してもパリウム, air とも先 進を認めなかった（図 4 右）.

内視鏡的には頝部食道後壁に5〜 6mm の瘦孔を認め た(図 5 左)。胸部食道は造影所見と同様に 2 つの䚻状

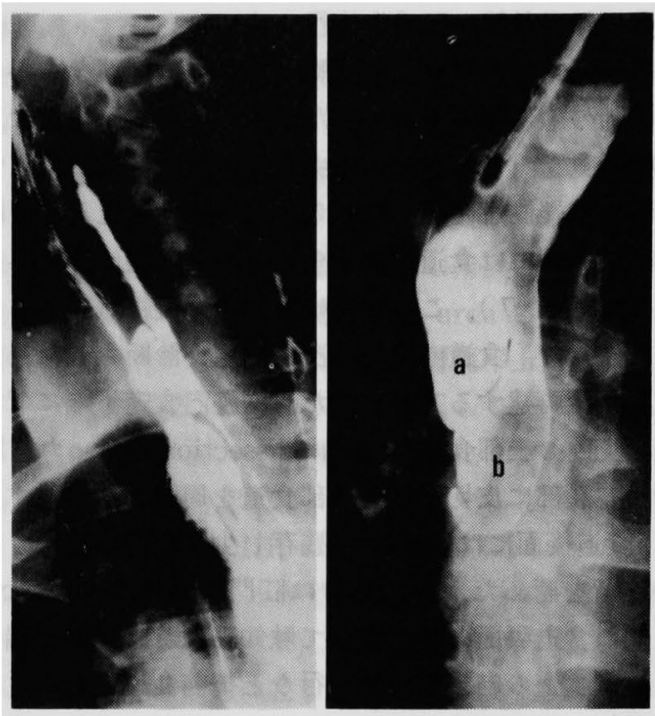

図 4 释口食道造影一昭和58年 3 月 31 日一, 左 : 頚部

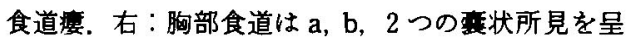
し, 完全閉塞している.

所見を示し同部より肛門側の内腔を見出だせないが， 衰状部分の表面は共に平滑な健常粘膜で覆われていた (図 5 右).

以上の所見を総合し, 膿胸, 縦隔炎による胸部食道 の周囲からの締め付けで同部が高度狭窄〜閉塞に宿っ たすのと判断, 閉塞局所へのアプローチにより食道を そのまま用いた修復が出来ることに期待し，昭和58年

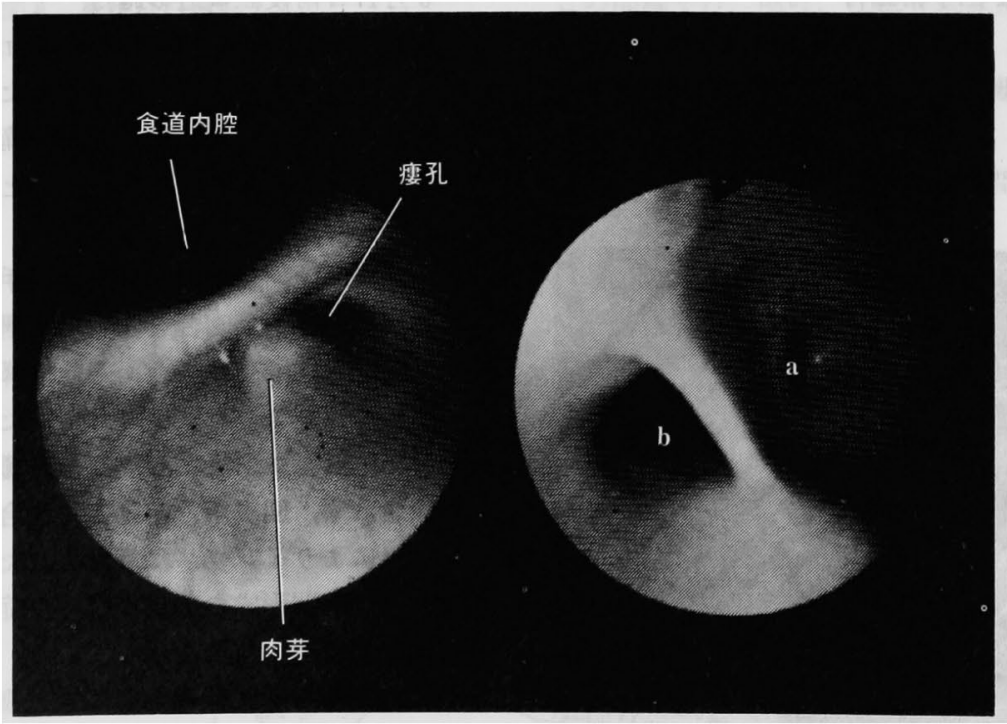

図 5 食道内視鏡一昭和 58 年 4 月 2 日一. 左：頝部食道後壁の瘦孔. 右：胸部食道, a, b は図 4 に対応する 
4 月19日当科第一回手術施行.

手術所見 : 右第 6 肋間開胸. 前回開胸創部を中心と して肺の府着は高度であったが中下糈隔には海着なく 炎症所見を見なかった. 術中内視鏡で中部食道の $2 つ$ の至状盲端位を確認しながら食道切開を加えるに盲端 より肛門側には食道粘膜を全く認めず内管は閉塞して いた（図 6,7)。この閉塞は周囲の都痕組織によるも のではなく，食道内县の一次的閉塞と診断された為食 道を切除再建する方針とした。胸腔内食道下端にて食 道を切断し上部食道は blunt dissectionを行った。閉 胸後左頝部に皮切を加え頊部食道を周囲より制離する と，食道後面には cavity が残存し少量の悪臭を伴 ら夜 の詝留を認めた。瘦孔入口は肛門側断端より $5 \sim 6 \mathrm{~cm}$ 口側の食道裏面に硬結として触知された。食道断端よ り口側食道の内腔の指診を行 5 と術前食道造影所見に 一致し，食道断端の約 $4 \mathrm{~cm}$ 口側の左側壁に弁状の毁痕 組織あるす右侧は柔らかく内空は充分に広かった，以 上の所見より，末だ fistula cavity は感染を伴っており 一期的食道再建を行ら事は不可能と判断, 食道裹面に リブ付きフラットドレーンを留置し, 左頝部に頝部食 道外瘦を造設した。

術後, 胸腔ドレーンと顏部フラットドレーンの交通 が確認されたが 1 カほどで自然閉鎖され両ドレーン とも抜去された。

6 月 6 日程口的食道造影により頝部食道の瘦孔の閉 鎖が確認されたため食道の再建を行らこととした。

6 月 7 日当科第 2 回手術施行

上腹部正中切開, 敬骨後結腸挙上食道再建術（端部 食道結腸吻合, 結腸胃吻合, 幽門形成術, 結腸結腸吻 合).

術後经過は特に問題なく，

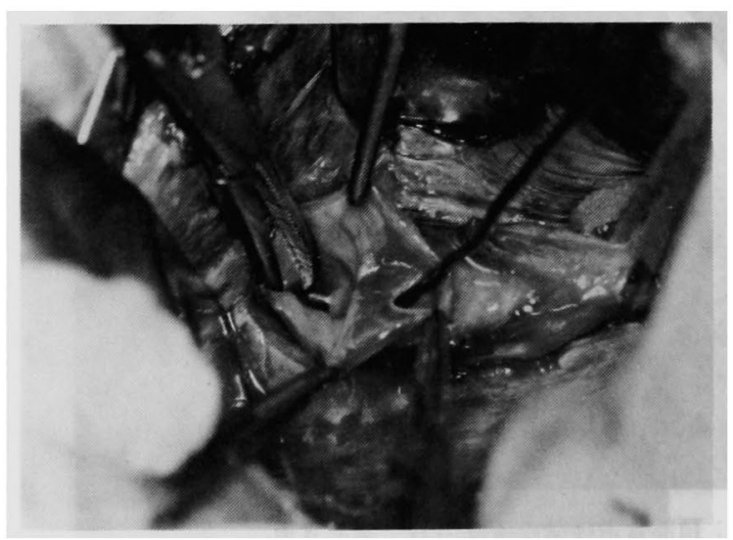

図 6 術中写真一昭和 58 年 4 月 19 日一
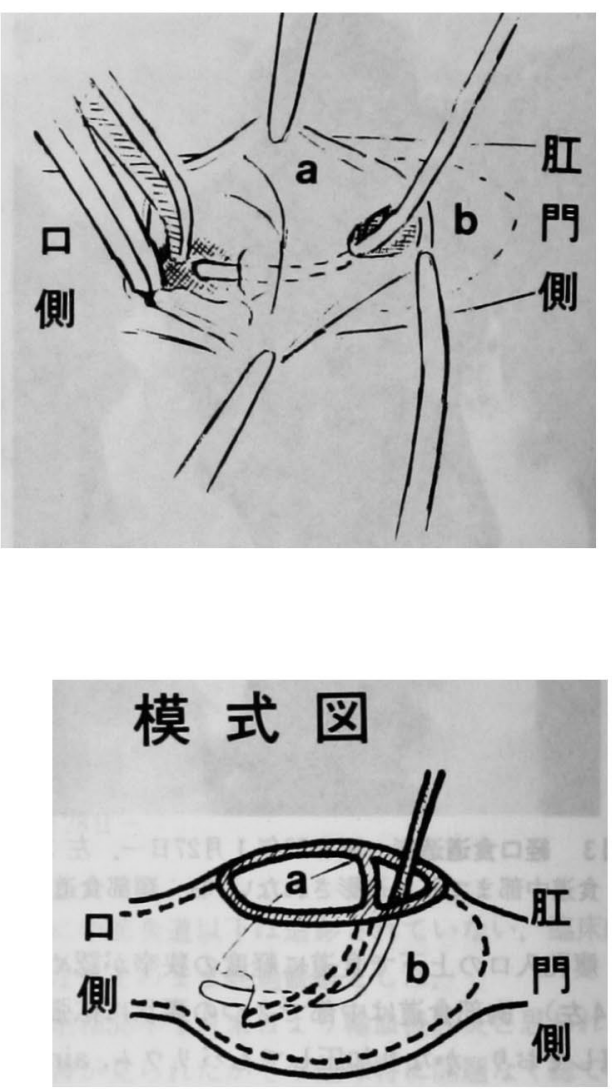

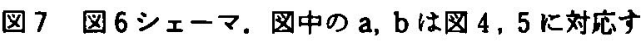
3

\section{6 月17日術後経口造影施行}

颀部食道結腸吻合部はやや stenoticたが leakage なし，同日タより経口食を再開した。

6 月19日タょり腹部膨満感と仙痛が出現。術後痹着 性イレウスと診断し, 再度食止めとして保存的治療を 試みたが軽快せず。

6 月21日再開腹術（当科第 3 回手術）施行

前回の結腸結腸吻合を中心に大網が結腸前面を覆い

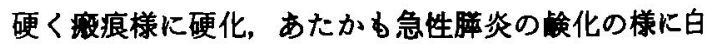
色化しており結腸を楴め付けていた。この大網を切除

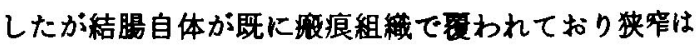
解除されず，回腸下行結腸側々吻合を圈いた。

これによりイレウスは解除されたか，难部食道結阳 吻合及び幽門形成の部位が強い炎症反応の為か術直後 には閉塞に近い㹟窄を示していた。

この狭窄す時間経過と共に通過良好となり6月29日 経口摄取再開

8 月 6 日常食撕取可能となり退院. 
現在受傷後 1 年 7 力月, 食道再建術後 12 力月半経過 し，良好な摄食状態を保っている（図 8).

病理所見：切除された食道は $13.5 \mathrm{~cm}$ 長で肛門側の 半分では内腔を確認できない. 食道長軸方向に切り開 くと幅2.8 5.5cm で図 9のことくく側半には白色調 で光沢のある粘膜上皮を認めるが (area A) 盲端部よ り肛門側では上皮の存在を確認できず(area B)．肛門

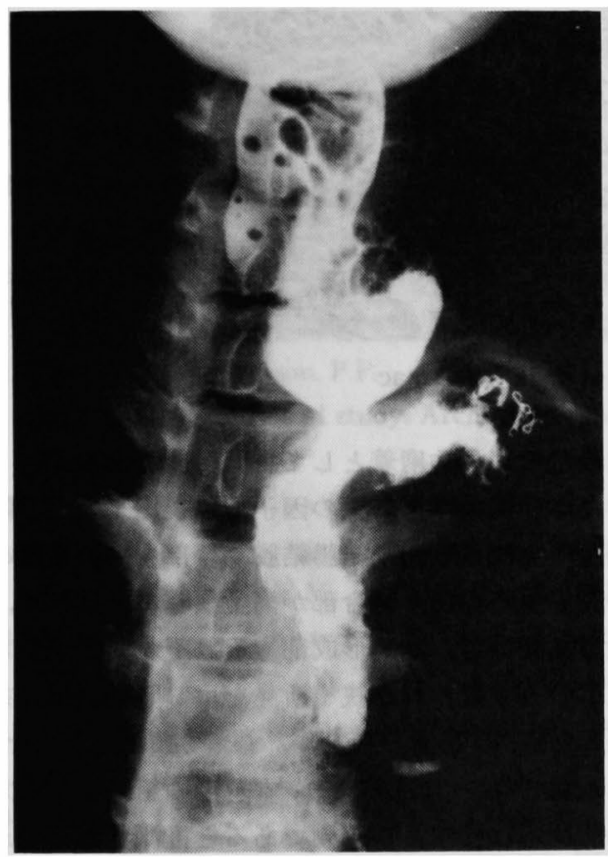

図 8 術後経口造影
側断端からわずかの間には白色調で上皮の存在を思わ せる部分があるが表面の平滑性は失われており粗造で ある(area C).

組織学的に area A は亘端部隔壁も含め正常重層扁 平上皮で覆われているが area Bでは上皮は全く欠

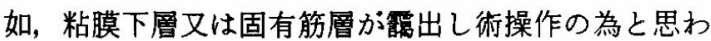
れる出血が認められる(図10左). area Cでは所々に 再生上皮と思われる非常に薄い重層扁平上皮を認める が粘膜固有層或いは粘膜下層の霣出している部分もあ る(図10右)，筇層，外膜層には線維化は認められるが 殆んど炎症所見を認めず。

\section{III. 考案}

経鼻胃管留置による食道狭乍については，欧米では Vinson ${ }^{12)}$ らをはじめとして多くの報告が見られる が3) 8), 本邦報告例は我々の調べ得る限りでは見出た すことが出来なかった．欧米報告例においても胃管留 置と食道狭窄との関連性については意見がまちまちで あり原疾患（消化性潰湯, 胆道疾患, 妊娠等）との関 連, gastro-esophageal reflux の誘発, 逆流した胃内容 の胸腔内食道内残留の助長等を想定し，逆流性食道炎 による狭窄とする考方方が強く(13)5)99, 局所血行, 血栓, 抗凝固剤による血腫等を原因として挙げているも の ${ }^{47) 10)}$ もる。. 留置期間は $2 \sim 30$ 日と ${ }^{215)}$ 様々で胃管抜 去から狭窄症状の発現までには通常 $2 \sim 3$ 力月を要し ている6)7.

本症例では胃管の留置期間は 6 日間と比較的短く, この間胸やけ，呕吐，吐血等逆流性食道炎を疑わせる
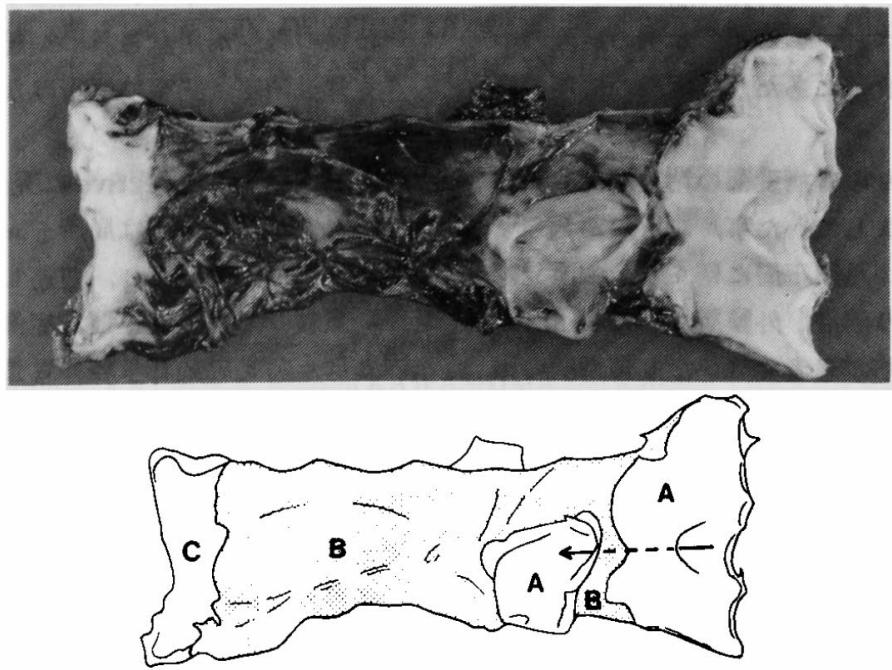

図 9 切除標本肉眼所見. A : area A, B : area B, C : area C (本文参照) 


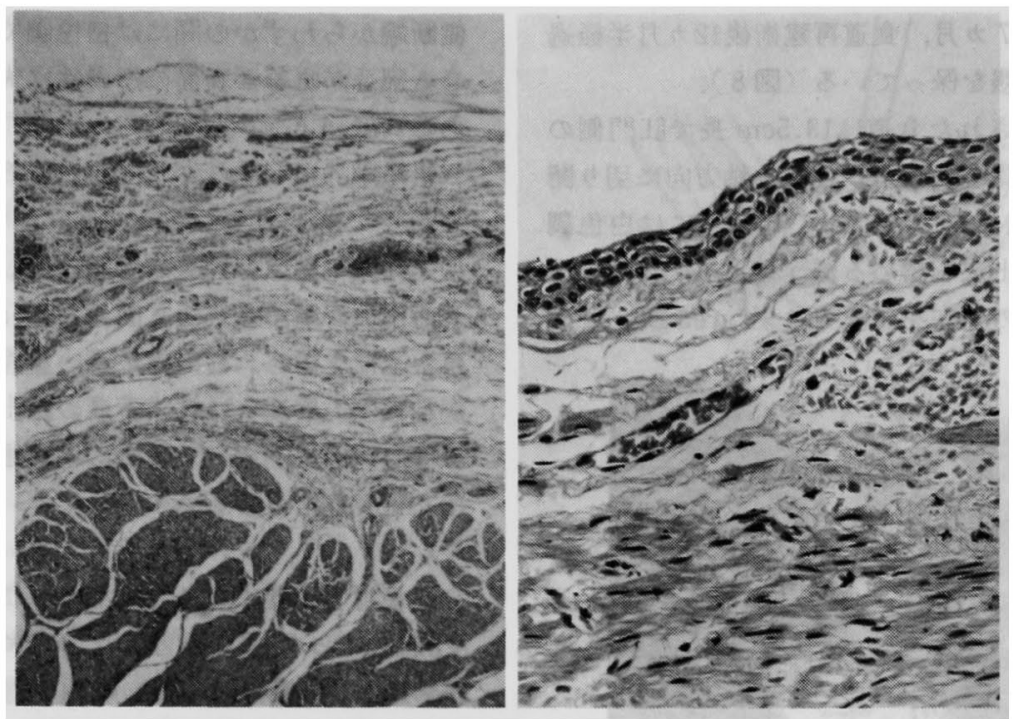

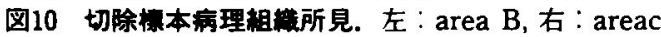

症状はなく，また胃酸分必に対し cimetidine が投与さ れており，抗㠜固刘の使用や出血㑯向もなかった。

一方，本例に使用された経算胃は赤ゴム（天然ゴ ム）製の物でありシリコン等より局所刺敞は大きいと

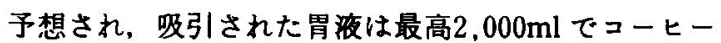
残淔様上過酸状態を疑わせる。 また頚部食道瘦と右胸 腔の交通を断つ目的で完全な仰卧位の保持を強いられ ており，唾液を含め释口摄取は一切禁しられていた。 これらの点は esophageal cleaningにとって不利に働 いたと思われる。

程基胃管によると言われる食道狭窄の殆どが胸部下 部食道に発生しており，狭窄は胸腔内陰圧に上る逆流 胃液の停滞の為と説明されているか，本例の病変の中 心も正にこの胸部下部食道にあたり，同様の機序が倠 いた事を示㗪する。

しかし本例で特徽的なのは病変部の粘膜が全く失わ れ食道内腔が完全に消失していた事，にるかかからず 炎症の場が殆んど粘膜, 粘膜下層に留まり術中所見, 病理組織所見が示す通り筋層，外膜層は殆んど intact であった点である．即ち本患者ではかなり短期間の出 来事として食道粘膜, 粘膜下層に限局した強い炎症が 起り，あるいは（経舆胃管抜去の際特に上皮がまつわ り付いて掖去された等の異常には気付かれていない が）何らかの原因で全周にわたる上皮の剝脱が起り， その後食道内を何物む通過する事がなかった為上皮娳 脱の治密過程として食道閉塞が完成されたと予想され る. 閉塞部の口側の秝室様所見も同様の機序による食
道前後壁の部分的空着として説明可能である.

また本症例では患者側の因子す無視出来ない。即ち， 再開腹所見に見る通り結腸結腸吻合部を中心に梗めて 強い炎症反応が起り吻合部が高度狭窄に宿った点, 頊 部食道結腸吻合，幽門形成部もそれぞれ術後過剩な組 織反応の為と思われる狭窄所見を呈し時間経過と共に 軽快した点, 本患者の術創が，すへて䫒著な hypertro. phic scar となった点等より，本患者の組織損傷に対寸 る局所反応は通常より過剩であると推測され，これる 胸部中部食道完全閉塞の一因であったと思われる.

食道の粘膜脱落に関しては他に剶離性食道炎が知ら れているが(1)-13)，これは豩離する粘膜の下で既に新し い粘膜の再生が用意されつつ起る現象であり。これに よる食道閉塞，猐窄の報告はなく本例とは明らかに異 る疾患である。

本症例は retrospectiveに見れば食道閉塞さえ起ら なければ頚部食道瘦は局所ドレナーシのみで充分治等 していた可能性があり，前述した様な数々の不利な条 件が重なって起った不運な症例と言えよう。しかし齐 因となったと思われる释胃管留置, 释口摄取禁止, 安静臥床等はごく一般的にとられる処置であり，本例 と同様の事態がたいつ起らぬとる限らない，その意 味で以下に挙げた各点には留意してしかるべきのと 考える。

経胃管にはシリコン等組織刺激性の少ない材質の すのを用いる。

経胃管留置中の患者の胃液が過酸状態を示す時怯 
積極的に制酸剤、H2 blocker 等を使用する.

経胃管留置中の患者を起座させる等，可能な限り

卧位のままとなる事を避ける。

特に本例のごとく esophageal cleaning にとって不 利な条件が重ったり，患者側因子としての過鄱組織反 応性の疑われる場合は，本症例を念頭に置いて経胃 管拔去後の德下状態を注意深く観察する。

$$
\text { IV.まとめ }
$$

外傷性預部食道漠の患者に発生した経舞胃管留置を 誘因とすると思われる胸腔内食道完全閉塞の症例を報 告した，㽞めて稀な条件下に起った事態とは思われる が個々の誘因に関してはごく一般的に見られるもので あり，释胃管留置に際しての留意点を明らかにすべ

く考察を加えた。

\section{文献}

1) Butt, H.R. and Vinson, P.P.: Esophagitis. II. A pathologic and clinical study. Arch. Otolaryng., 23 : 550-572, 1936.

2) Vinson, P.P.: Cicatrichial (Benign) stricture of esophagus following vomiting and intubation. West Virginia. M. J., 37: 349-352, 1941.

3) Mason, L.B., Ausband, J.R. and WinstonSalemn, N.C.: Benign stenosing espohagitis associated with vomiting and intubation. Surgery, 32(1) : 10-16, 1951.

4) Douglas, W.K.: Oesophageal strictures associated with gastroduodenal intubation. $\mathrm{Br}$. J. Surg., 43 : 404-409, 1955-6.
5) Bingham, J.A.W.: Oesophageal strictures after gastric surgery and naso-gastric intubation. Br. Med. J., 4 : 817-819, 1958.

6) Waldman, I. and Berlin, L.: Stricture of the esophagus due to nasogastric intubation. Am. J. Roentgenol. Radium. Ther. Nucl. Med., 94 : 321 $-324,1965$.

7) Banfield, W.J. and Hurwitz, A.L. : Esophageal stricture associated with nasogastric intubation. Arch. Int. Med., 134 : 1083-1086, 1974.

8) Gupta, S.: Esophageal stricture following nasogastric intubation. Asian Med. M., 20(7) : 413-416, 1977.

9) Nagler, R. and Spiro, H.M.: Persistent gastroesophageal reflux induced during prolonged gastric intubation. New Engl J. Med., 269(10): 495-500, 1963.

10) Straus, G.D. : Stricture of the esophagus associated with operation for duodenal ulcer. Arch. Otolaryng., 51 : 165-171, 1950.

11) Patterson, T.C.: A simple oesophageal cast. J. Path. Bact., $40: 559-569,1935$.

12）関欢英一，吉次喜久，河野誠ほか：劋離性食道炎 と考えられる1 例. Progress of Digestive Endoscopy 50(12): 133-136, 1976.

13）鹿戸福子，藤本秀明，大草敏史结か：剝離性食道资 の 1 例，胃と腸，18(11)：1205-1208，1983.

\title{
A CASE OF COMPLETE OBSTRUCTION OF THE THORACIC ESOPHAGUS ASSOCIATED WITH NASOGASTRIC INTUBATION FOLLOWING TRAUMA OF THE CERVICAL ESOPHAGUS
}

\author{
Harushi UDAGAWA, Masahiko TSURUMARU, Masatoshi SUZUKI, Yoshimasa ONO, \\ Goro WATANABE and Hiroshi AKIYAMA \\ Department of Surgery, Toranomon Hospital \\ Masamitsu UNAGAMI and Mitsuru HARA \\ Department of Pathology, Toranomon Hospital \\ Takuzo KATAOKA, Kiyoshi KAWASHIMA and Katsumi TAKAHASHI \\ Department of Surgery, Musashino Red Cross Hospital
}

Though nasogastric intubation has been pointed out as a cause of benign acquired esophageal stenosis, no report of complete obstruction can be found. This is the first report of complete esophageal obstruction probably due to this intubation.

A 19-year-old girl accidentally stabbed herself with chopsticks in the upper cervical esophagus. Two hours later, she was brought to a hospital for severe dyspnea caused by huge retropharyngeal emphysema. This ruptured into the right pleural cavity and she had an emergency drainage operation. The nasogastric tube was left indwelling for 6 days 
after the operation. The patient was then transferred to Toranomon Hospital, and her esophagus, which was found completely obstructed in the lower half, was successfully resected and reconstructed.

Histological examination showed the cause of the esophageal obstruction to be circular detachment of the mucosa due to acute superficial inflammation and postinflammatory healing process. The constitutional factors were also suspected, because her incisional wounds became hypertrophic scar and she developed early postoperative bowel obstruction due to excessive adhesion.

Though this case seems to be a very rare one in which several unfavorable factors coincided, each factor alone is not uncommon. From this point of view, precautions to take during nasogastric intubation are discussed.

Key words: Acquird benign esophageal obstruction, Trauma of esophagus, Naso-gustric tube 